\title{
Drought alters plant-soil feedback effects on biomass allocation but not on plant performance
}

\author{
Rutger A. Wilschut $\mathbb{D}$ - Mark van Kleunen
}

Received: 13 October 2020 / Accepted: 27 January 2021 / Published online: 10 February 2021

(C) The Author(s) 2021

\begin{abstract}
Aims Drought events can alter the composition of plant and soil communities, and are becoming increasingly common and severe due to climate change. However, how droughts affect plant-soil feedbacks is still poorly understood. Plants accumulate species-specific rhizosphere communities, and droughts may have varying impacts across plant species and soil biota. We therefore tested the hypothesis that drought alters plant-soil feedbacks differently among closely related plant species that differ in their preferences for soil moisture.

Methods In a two-phase greenhouse experiment, we first conditioned grassland soil with seven Geranium species and, as controls, we conditioned soil with a grass species or left soil unplanted. In the second phase, we grew the Geranium species in conspecific, grassconditioned and unplanted soil, maintained soil moisture at $5 \%, 10 \%$ or $20 \%(\mathrm{w} / \mathrm{w})$, and determined biomass responses after 35 days.

Results Independent of conditioning, plants showed a weaker performance with decreasing soil moisture. Under the driest conditions, soil conditioning by conspecifics most negatively affected relative root weight in

Responsible Editor: Kenny Png .

R. A. Wilschut $(\bowtie) \cdot$ M. van Kleunen
Ecology Group, Department of Biology, University of Konstanz,
Konstanz, Germany
e-mail: rutger.wilschut@ uni-konstanz.de
M. van Kleunen
Zhejiang Provincial Key Laboratory of Plant Evolutionary
Ecology and Conservation, Taizhou University, Taizhou, China
\end{abstract}

comparison to plants growing in unplanted control soil, while the effects of conspecific conditioning on relative root weights were species-specific when compared to plants grown in grass-conditioned control soil. Conclusions We conclude that decreased soil moisture modified plant-soil feedback effects on biomass allocation, and that these modifications acted in speciesspecific ways. However, drought effects on plant-soil feedbacks were subtle, and did not affect overall plant performance. Therefore, plant-soil feedback effects on plant performance during a drought event may be limited in comparison with the direct effects of drought.

Keywords Plant-soil feedbacks · Drought · Biomass allocation · Geranium

\section{Introduction}

Climate change increases the frequency of drought events worldwide (Shukla et al. 2019), leading to decreasing primary productivity of terrestrial plant communities and alterations of plant community composition (Ciais et al. 2005; Kardol et al. 2010; Wu et al. 2011). Through reductions of microbial biomass and belowground diversity, drought events also modify communities of soil organisms (Maestre et al. 2015; Pugnaire et al. 2019; Sheik et al. 2011). As soil communities play a crucial role for plant health (Bardgett and van der Putten 2014; Berendsen et al. 2012), it is important to understand whether and how drought events alter the interactions between plants and their 
co-associated soil biota, especially those that directly affect plant performance (De Long et al. 2019a; Pugnaire et al. 2019).

Through variation in structural and chemical root traits (Cortois et al. 2016; van Dam and Bouwmeester 2016; Wilschut et al. 2019), plants accumulate speciesspecific rhizosphere communities of soil organisms, including mutualists, such as mycorrhizal fungi and plant growth-promoting bacteria, and antagonists, such as microbial pathogens and root-feeding nematodes (Berendsen et al. 2012; Bezemer et al. 2010). Together, these organisms affect the performance of their host and neighbouring plants, but also subsequent generations of plant individuals via a mechanism known as plant-soil feedback (van der Putten et al. 2013). Plant-soil feedback effects can range from negative to positive, and soil biota can contribute to the natural succession of plant communities, grassland vegetation dynamics and plant rarity through this mechanism (De Deyn et al. 2003; Kardol et al. 2006; Klironomos 2002; van der Putten et al. 1993).

Droughts can modify plant-soil feedbacks both during the process of soil community conditioning as well as during the feedback response phase. Firstly, through changes in soil moisture, as well as through changes in root exudation patterns in response to altered water availability, droughts can directly and indirectly alter soil community composition, with possible effects on subsequent plant performance ('drought legacy effects'; de Vries et al. 2012; Kaisermann et al. 2017; Williams and de Vries 2020). These drought legacy effects will especially be strong when drought alters the relative abundances of plant-mutualistic and plant-antagonistic organisms. For example, droughts can increase the relative abundance of mycorrhizal fungi (de Vries et al. 2018), or decrease the suppression of soil pathogens (Meisner and de Boer 2018) or root-feeding nematodes (Franco et al. 2019). Secondly, plant-soil feedbacks will also change when drought directly alters the impacts of soil organisms on plants during the feedback phase. For example, plant species that successfully associate with mycorrhizal fungi may especially benefit from this association under dry conditions, as mycorrhiza can alleviate drought stress (Augé 2001; Li et al. 2019). Likewise, drought may either increase or decrease plant susceptibility against pathogen and root-feeding nematode attack (Atkinson and Urwin 2012). In this way, drought may also alter the direct impacts of speciesspecific soil communities on plant performance, thereby altering plant-soil feedback variation among plants. However, such drought-mediated plant-soil feedback effects that arise during the feedback phase have rarely been examined (Fry et al. 2018; Meijer et al. 2011).

In this study, we explored how different soilmoisture treatments affect feedback effects of soil communities conditioned by conspecific plant species on plant performance of seven species of Geranium. In an earlier study, these species developed species-specific soil communities that differently affected subsequent conspecific plant performance (Wilschut et al. 2019). Moreover, in nature these species vary in their preferred abiotic conditions, and differ in their Ellenberg indicator values for soil moisture (Hill et al. 1999). This makes them a suitable group of plant species to test whether soil-mediated effects of drought on plant performance can differ among plant species, while also examining direct effects of soil moisture on plant performance. We tested the hypothesis that among this set of species with different Ellenberg indicator values for soil moisture, soil moisture and soil communities conditioned by conspecifics interactively affect plant performance in a plant species-specific manner. To test our hypothesis, we set up a greenhouse experiment to determine plant performance and biomass allocation of these species under three different soil-moisture regimes in soil conditioned by conspecifics, unconditioned soil and soil conditioned by a widespread grass species.

\section{Methods}

Our greenhouse experiment consisted of two phases. In the first phase, we conditioned soils with each of the seven Geranium species (conspecific conditioning). We also established two soil treatments that served as control for soil conditioned by conspecific plants: unplanted control soil, and soil conditioned by the grass species Bromus hordeaceus (grass conditioning), a native and widespread species across Europe. This grassconditioned control treatment was added to create a soil with a distinct heterospecific, plant-associated soil microbial community, which due to the presence of a plant likely more closely resembled the Geranium-conditioned soil in terms of soil nutrient content.

In the second phase of the experiment, we examined drought effects on Geranium plant-soil feedbacks, by comparing the growth of the seven species of Geranium in conspecific, unplanted control and grass-conditioned 
soils under $5 \%, 10 \%$ and $20 \%$ gravimetric soilmoisture content (Fig. 1).

Plant species and germination procedure

All seven Geranium species are native to Europe. Most of the species are annual grassland herbs, which, based on Ellenberg values, grow under moderately wet to moderately dry conditions (Table 1). Seeds of all species originated from natural populations in the Netherlands and Germany (Table 1). For G. purpureum, seeds were collected from plants grown in a greenhouse at NIOO-KNAW (The Netherlands), which were the second generation offspring of plants from a natural population in The Netherlands. Seeds of all other species were directly collected from the field. Bromus hordeaceus seeds were obtained from Rieger-Hofmann GmbH (BlaufeldenRaboldshausen, Germany). For all species, we germinated seeds on moistened standard, unsterilized potting soil in a climatized greenhouse $\left(20 / 14^{\circ} \mathrm{C}\right.$; $16 \mathrm{~h}$ light/8 h dark).

\section{Conditioning phase}

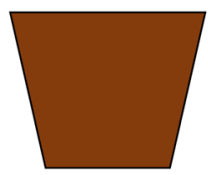

Conditioning

Unplanted control

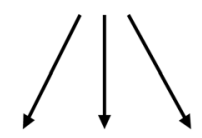

Feedback phase

Soil moisture

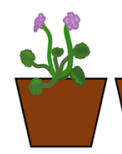

$5 \%$

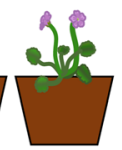

$10 \%$

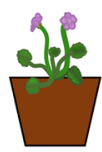

$20 \%$

Fig. 1 Schematic overview of the experimental set-up. In the conditioning phase, three soil types were created by planting soils with two conspecific Geranium plants (Conspecific), leaving them unplanted (Unplanted control) or planting them with two Bromus hordeaceus seedlings (Grass control). This was performed for seven different Geranium species (Table 1), and all treatments were replicated five times. In the feedback phase, each
Conditioning phase

In the same climatized greenhouse compartment, we established $1052 \mathrm{~L}$ pots, each containing $1200 \mathrm{~g}$ of a sand and vermiculite mixture (1:1 ratio, based on volume) thoroughly mixed with $300 \mathrm{~g}$ of sieved field soil (mesh size $10 \mathrm{~mm}$ ). This field soil was collected in a species-rich grassland area near the university of Konstanz (Hockgraben, Konstanz; WGS 84: $47.688 \mathrm{~N}, 9.192 \mathrm{E})$. We planted 35 pots (7 species $\times 5$ replicates) with two conspecific Geranium seedlings in each pot (conspecific conditioning), 35 pots with two Bromus hordeaceus seedlings in each pot (the grass conditioning control), and left the remaining 35 pots empty (the unplanted conditioning control). We arranged the pots according to a randomized block design with five replicate blocks. Throughout the conditioning phase, planted pots were watered equally, while unplanted pots were watered less often to compensate for plant transpiration. Each pot received $500 \mathrm{ml}$ of nutrient solution (1 $\mathrm{g} / \mathrm{L}$ Universol ${ }^{\circledR}$ Blue; ICL Deutschland, Nordhorn, Germany) in total, which was divided over five watering
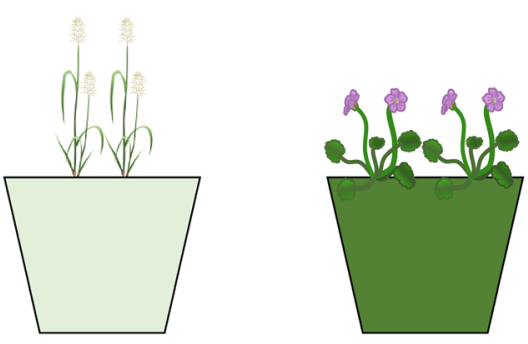

Grass control

Conspecific
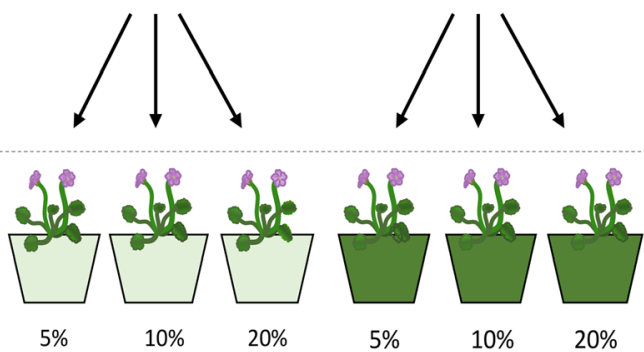

experimental replicate soil from the first phase was split into three new experimental units. All three conditioned soil types were planted with conspecific Geranium individuals. Soil in each unit was then maintained at either $20 \%, 10 \%$ or $5 \%(\mathrm{w} / \mathrm{w})$ soil moisture for most of the remaining time of the experiment (see Methods section) 
Table 1 Seed origin of Geranium species used in the present study, and species Ellenberg values for soil moisture (EL_M; based on Hill et al. 1999)

\begin{tabular}{|c|c|c|c|c|}
\hline Species & Location & Latitude & Longitude & EL_M \\
\hline Geranium dissectum & Wageningen, NL & 51.959453 & 5.65838 & 5 \\
\hline Geranium molle & Wageningen, NL & 51.959453 & 5.65838 & 5 \\
\hline Geranium purpureum & Leiden, NL* & 52.144410 & 4.49941 & 3 \\
\hline Geranium pusillum & Wageningen, NL & 51.960901 & 5.65553 & 4 \\
\hline Geranium pyrenaicum & Konstanz, DE & 47.667 & 9.1994 & 4 \\
\hline Geranium robertianum & Jena, DE & 50.930605 & 11.58564 & 6 \\
\hline Geranium rotundifolium & Wageningen, NL & 51.965554 & 5.67321 & 4 \\
\hline
\end{tabular}

*For the current study seeds were collected from plants grown in a greenhouse at NIOO-KNAW (Wageningen, Netherlands), which were germinated from seeds collected from the indicated location.

Ellenberg values of the study species range from 3-6 on a scale of $1-9$, where the lower values indicate drierconditions

occasions. After eight weeks of conditioning, soil from each individual pot was carefully separated from the roots using a 4-mm sieve, and then stored in a cold room $\left(10^{\circ} \mathrm{C}\right)$ until the start of the feedback phase.

Feedback phase with soil-moisture treatment

Three weeks after the end of the conditioning phase, we first determined soil moisture of all individual pots by drying a $15 \mathrm{~g}$ soil sample at $105^{\circ} \mathrm{C}$ for 24 hours. The remaining soil of each pot from phase one was then divided over three $0.5 \mathrm{~L}$ pots, with each pot containing $300 \mathrm{~g}$ dry weight soil. All pots were watered to $20 \%$ (w/w) soil moisture content. Thereafter, a single Geranium seedling was transplanted into each pot containing unplanted control soil or soil conditioned by a conspecific or the grass Bromus hordeaceus (Fig. 1). This resulted in 315 pots $(7$ species $\times 3$ soil conditioning treatments $\times 3$ moisture regimes $\times 5$ replicates). However, due to poor germination of G. rotundifolium and G. pyrenaicum, we did not grow these species in grassconditioned soils, and reduced replication for the other treatments to 4 replicates (resulting in a final number of 273 pots). For each seedling, we determined leaf number and the length and width of the biggest leaf on the day of planting. Soil moisture was kept at $20 \%$ (w/w) for the first 8 days of the feedback phase. During that period, each pot received $50 \mathrm{~mL}$ of nutrient solution $\left(1 \mathrm{~g} / \mathrm{L}\right.$ Universol ${ }^{\circledR}$ Blue; ICL Deutschland, Nordhorn, Germany). After that, we started the application of three watering treatments: soils were either kept at $20 \%$ soil moisture, or watering was reduced to decrease soil moisture until $10 \%$ or $5 \%(\mathrm{w} / \mathrm{w})$. Plants that were in very poor condition at the start of the soil-moisture treatment were removed from further analysis $(\mathrm{N}=3)$. Soil-moisture treatments were maintained by weighing and watering the pots every second day for the first 10 days of the drought treatment, after which we increased this procedure to 5-6 times per week for the rest of the experiment. To prevent plant mortality, pots that received the $5 \%$ soil-moisture treatment were recovered to $10 \%(\mathrm{w} / \mathrm{w})$ soil moisture for two 3-day periods, starting on the 7th and 16th day after the start of the drought treatment, respectively. To avoid potential pot limitation, plants were harvested five weeks after planting. Aboveground parts of the plants were clipped, dried at $70^{\circ} \mathrm{C}$ and weighed. Roots were carefully separated from the soil, washed, dried at $70^{\circ} \mathrm{C}$ and weighed.

\section{Analyses}

All statistical analyses were performed in $\mathrm{R}$ version 3.6.1 (R Core Development Team 2012). We analysed and visualized plant-soil feedback responses in two separate ways. Firstly, we calculated two plant-soil feedback values: (1) $\mathrm{PSF}_{\text {unplanted }}=\mathrm{Ln}$ (response in conspecific soil/response in unplanted control soil), calculated for all seven species, and (2) $\mathrm{PSF}_{\text {grass }}=$ $\mathrm{Ln}$ (response in conspecific soil/response in grassconditioned control soil), calculated for the five species for which biomass was determined in grass-conditioned soil. Secondly, we compared plant biomass responses to the three conditioned soil types. For this, we created two datasets, one containing the biomass data in conspecific and unplanted control soil for all seven species, and one 
containing data of the five plant species that we had grown in all three conditioned soil types. For the two sets of biomass data and the two sets of calculated plantsoil feedback values, we performed separate analyses for total biomass, shoot biomass, root biomass and relative root weight (root biomass/total biomass).

Prior to the analyses of biomass responses, we $\log _{10^{-}}$ transformed the biomass and relative root weight data to improve normality and homoscedasticity of the residuals. To control for initial differences in plant biomass in the feedback phase, we estimated the initial plant size by multiplying leaf number with the length $\times$ width of the largest leaf. For all analyses, we used mixed linear models (lmer-function in lme4; Bates et al. 2015). We modelled biomass responses with the 'block' term as random effect, 'initial plant size' as covariate and the 'species', 'conditioning' and 'soil moisture' terms and all their possible interactions as fixed effects. For each species, we also analysed models with 'initial plant size' as covariate and 'conditioning' and 'soil moisture' as fixed effects, to evaluate the strength of these effects on the biomass of the individual species. Plant-soil feedback values PSF $_{\text {unplanted }}$ and PSF $_{\text {grass }}$ were modelled with 'block' as random effect and 'species' and 'moisture' and the 'species*moisture' interaction term as fixed effects. For all models, p-values were calculated using the Anova-function (car-package; Fox et al. 2012). Post-hoc analyses were performed using least square means comparisons with Tukey-adjustments for multiple comparisons (lsmeans in the 'Emmeans' package; Lenth et al. 2018). Finally, to check whether variation in plant-soil feedback effects may be explained by differences in plant nutrient uptake in the conditioning phase, we tested, for each species separately, the correlation between Geranium or Bromus biomass at the end of the first phase and Geranium biomass at the end of the second phase.

\section{Results}

Plant-soil feedback measures

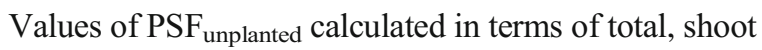
and root biomass were generally negative, but did not differ among soil-moisture-treatment levels, nor among species (Fig. S1). The $\mathrm{PSF}_{\text {unplanted }}$ effect on relative root weight, however, was significantly lower under the $5 \%$ soil-moisture treatment than under the $10 \%$ soil- moisture treatment $\left(\mathrm{X}^{2}=8.9, d f=2, \mathrm{p}<0.05\right.$; Fig. 2a). This indicated that, under the driest conditions, plants had a lower relative root weight when grown in soil conditioned by conspecifics compared to plants grown in unplanted soil.

For total, shoot and root biomass, values of PSF $_{\text {grass }}$ (i.e. growth responses in conspecific soil relative to growth responses in grass-conditioned control soil) were variable but did not significantly differ among species or soil-moisture-treatment levels (Fig. S1). $\mathrm{PSF}_{\text {grass }}$ values of relative root weight were interactively affected by plant species and soil moisture $\left(X^{2}=20.1\right.$, $d f=8, \mathrm{p}<0.01)$. That is, in the $5 \%$ soil-moisture treatment, plant species showed significant variation in PSF $_{\text {grass }}$ values, while such variation was absent under higher soil-moisture levels (Fig. 4b). Geranium molle

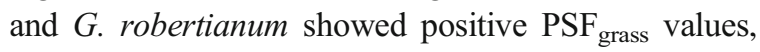
indicating greater relative root weights in conspecific than in grass-conditioned control soils. In contrast, G. purpureum showed a clearly negative $\mathrm{PSF}_{\text {grass }}$ value (Fig. 2b).

\section{Plant biomass}

Total grass or Geranium biomass in the conditioning phase was not correlated to Geranium biomass in the feedback phase for any of the Geranium species (Table S1). Across species and soil conditioning treatments, aboveground, belowground and total biomass in the feedback phase decreased with decreasing soil moisture (Table 2; Fig. 3). This soil-moisture effect on plant biomass was found in the analyses of the dataset containing unplanted control- and conspecific soil treatments of 7 Geranium species as well as in the analyses of the dataset containing all three soil conditioning treatments of 5 Geranium species (Table 2; Figs. 3 and 4). Average biomass production of all seven species was greater in unplanted control soil than in conspecific soil (Table 2; Fig. 3). Average total and shoot biomass of the five plant species that were grown in all three conditioned soil types was higher in unplanted control soil than in both conspecific and grass-conditioned control soil (Table 2; Fig. 4). Root biomass of these species was significantly greater in unplanted control soil than in conspecific soil, while biomass in grass-conditioned control soil was intermediate and did not differ from biomass in unplanted control or conspecific soil (Table 2; Fig. 4). Average biomass production in 


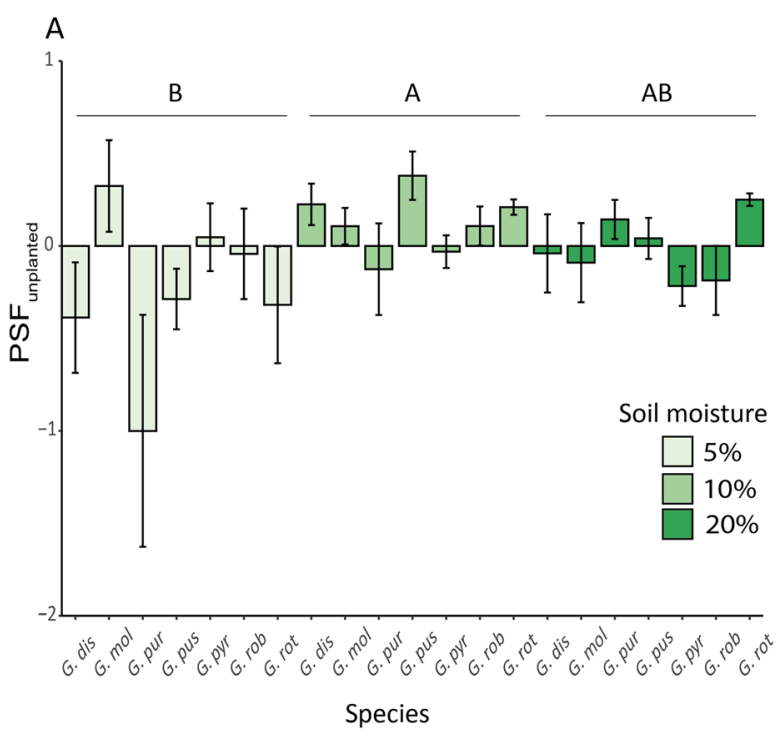

Fig. 2 Plant-soil feedback effects on relative root weight (RRW) of Geranium species under three soil moisture levels, calculated using the RRW of plants grown in conspecific soil compared to (A) unplanted soil or (B) grass-conditioned soil. PSF unplanted $_{\text {and }}$ $\mathrm{PSF}_{\text {grass }}$ for each species was calculated as $\mathrm{Ln}$ (RRW of plant grown in conspecific soil/RRW of plant grown in unplanted soil) and $\mathrm{Ln}(\mathrm{RRW}$ of plant grown in conspecific soil/RRW of plant

conspecific soil did not significantly differ from biomass production in grass-conditioned control soil. Among the seven different Geranium species grown in conspecific and unconditioned soil, and among the 5 species grown in all three soil conditioned soil types, there was significant variation in total, shoot and root biomass production (Table 2; Fig. 3), which was independent from soilmoisture and soil-conditioning effects. Separate analyses of soil moisture and conditioning effects on the total biomass of individual species showed that the effect of soil moisture was always significant, and stronger than the effect of soil conditioning, which was not always significant (Table S2).

Average relative root weight of all seven species in unplanted control and conspecific soil was interactively affected by soil moisture and soil conditioning (Table 2). In unplanted control soil, relative root weight tended to be greatest with $20 \%$ soil moisture, while in conspecific soil relative root weight tended to be greatest with $10 \%$ soil moisture (Fig. 3). However, in both soil conditioning treatments, relative root weight did not statistically differ between the $10 \%$ and $20 \%$ soil moisture treatments, and was lowest when plants were subjected to the $5 \%$ soil moisture treatment

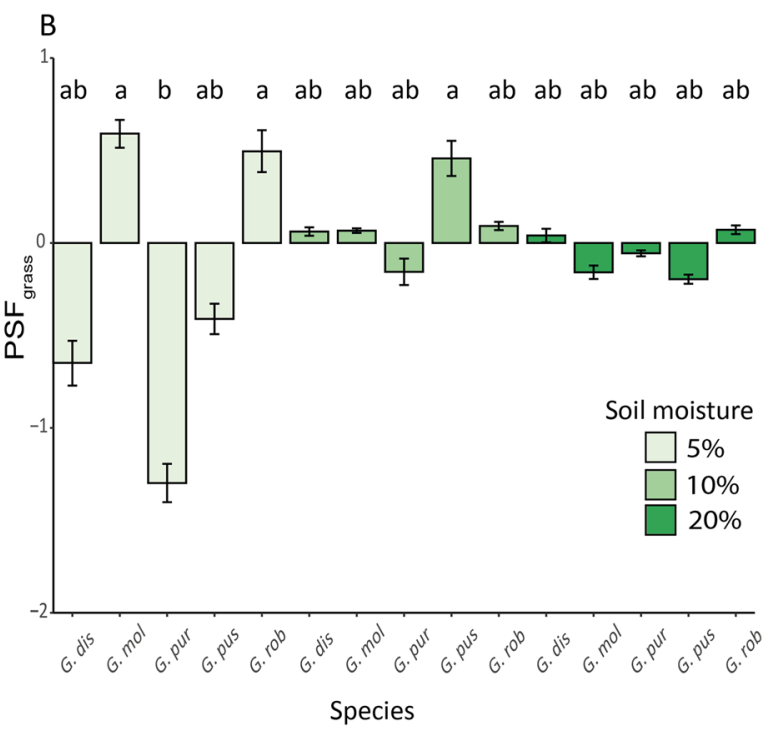

grown in grass-conditioned soil), respectively (see Methods section). Soil-moisture levels (w/w) are colour-coded. Capital letters represent significant differences between soil-moisture levels based on post-hoc analysis, and small letters indicate significant differences between plant species. Bars represent means \pm standard errors

(Fig. 3). Across the conspecific and unplanted control treatments, the seven plant species significantly differed in average relative root weight (Table 2), and this variation tended to depend on soil moisture (Table 2). Comparable plant-species effects on relative root weight were found in the analysis for the five species on all three conditioned soil types (Fig. S2). In this analysis, however, there was marginally significant support for an interactive effect between species, soil moisture and soil conditioning (Table 2, Fig. S2). In line with the analysis results of all 7 species across unplanted control and conspecific soil, relative root weight of the 5 species across all three soil types was lowest in pots with $5 \%$ soil moisture, and equally high in pots with $10 \%$ and $20 \%$ soil moisture (Table 2; Fig. 4).

\section{Discussion}

Our results show that soil moisture can alter plant-soil feedback effects on plant-biomass allocation, and thereby add to the evidence that soil moisture alters plant-soil feedback outcomes (Fry et al. 2018; Kaisermann et al. 2017). However, in line with a previous study on SouthAmerican tree seedlings (Meijer et al. 2011), we did not 
Table 2 Effects of fixed factors 'plant species', 'soil conditioning' and 'soil moisture', and all possible interactions, on total biomass, shoot biomass, root biomass and relative root weight

\begin{tabular}{|c|c|c|c|c|c|c|c|c|c|c|c|c|}
\hline & \multicolumn{12}{|c|}{ Conspecific and unconditioned control soils (7 species) } \\
\hline & \multicolumn{3}{|c|}{ Total Biomass } & \multicolumn{3}{|c|}{ Shoot Biomass } & \multicolumn{3}{|c|}{ Root Biomass } & \multicolumn{3}{|c|}{ Relative Root Weight } \\
\hline & $X^{2}$ & $d f$ & $\mathrm{p}$ & $\mathrm{X}^{2}$ & $d f$ & $\mathrm{p}$ & $X^{2}$ & $d f$ & $\mathrm{p}$ & $\mathrm{X}^{2}$ & $d f$ & $\mathrm{p}$ \\
\hline Species (S) & 61.3 & 6 & $<0.001$ & 85.0 & 6 & $<0.001$ & 34.1 & 6 & $<0.001$ & 161.6 & 6 & $<0.001$ \\
\hline Conditioning $(\mathrm{C})$ & 10.7 & 1 & $<0.01$ & 11.5 & 1 & $<0.001$ & 8.0 & 1 & $<0.01$ & 0.8 & 1 & 0.37 \\
\hline Moisture (M) & 427.8 & 2 & $<0.001$ & 361.1 & 2 & $<0.001$ & 529.3 & 2 & $<0.001$ & 231.5 & 2 & $<0.001$ \\
\hline $\mathrm{S}^{*} \mathrm{C}$ & 4.6 & 6 & 0.59 & 4.7 & 6 & 0.58 & 7.3 & 6 & 0.29 & 5.1 & 6 & 0.53 \\
\hline $\mathrm{S} * \mathrm{M}$ & 11.8 & 12 & 0.46 & 11.3 & 12 & 0.51 & 15.4 & 12 & 0.22 & 20.7 & 12 & 0.05 \\
\hline $\mathrm{C}^{*} \mathrm{M}$ & 1.5 & 2 & 0.47 & 1.6 & 2 & 0.44 & 3.0 & 2 & 0.22 & 8.0 & 2 & $<0.05$ \\
\hline \multirow[t]{4}{*}{$\mathrm{S} * \mathrm{C} * \mathrm{M}$} & 6.4 & 12 & 0.89 & 5.7 & 12 & 0.93 & 13.8 & 12 & 0.32 & 15.1 & 12 & 0.23 \\
\hline & \multicolumn{12}{|c|}{ Conspecific, grass-conditioned and unconditioned control soils (5 species) } \\
\hline & \multicolumn{3}{|c|}{ Total Biomass } & \multicolumn{3}{|c|}{ Shoot Biomass } & \multicolumn{3}{|c|}{ Root Biomass } & \multicolumn{3}{|c|}{ Relative Root Weight } \\
\hline & $X^{2}$ & $d f$ & $\mathrm{p}$ & $\mathrm{X}^{2}$ & $d f$ & $\mathrm{p}$ & $X^{2}$ & $d f$ & $\mathrm{p}$ & $X^{2}$ & $d f$ & $\mathrm{p}$ \\
\hline Species (S) & 98.2 & 4 & $<0.001$ & 138.5 & 4 & $<0.001$ & 9.6 & 4 & $<0.05$ & 113.6 & 4 & $<0.001$ \\
\hline Conditioning $(\mathrm{C})$ & 14.5 & 2 & $<0.001$ & 16.1 & 2 & $<0.001$ & 7.7 & 2 & $<0.05$ & 1.2 & 2 & 0.54 \\
\hline Moisture (M) & 538.1 & 2 & $<0.001$ & 471.9 & 2 & $<0.001$ & 594.4 & 2 & $<0.001$ & 269.1 & 2 & $<0.001$ \\
\hline $\mathrm{S} * \mathrm{C}$ & 5.2 & 8 & 0.74 & 5.4 & 8 & 0.71 & 8.5 & 8 & 0.38 & 14.1 & 8 & 0.08 \\
\hline $\mathrm{S} * \mathrm{M}$ & 13.6 & 8 & 0.09 & 12.7 & 8 & 0.12 & 13.1 & 8 & 0.11 & 11.0 & 8 & 0.20 \\
\hline $\mathrm{C} * \mathrm{M}$ & 2.1 & 4 & 0.71 & 2.3 & 4 & 0.68 & 2.5 & 4 & 0.64 & 7.1 & 4 & 0.13 \\
\hline $\mathrm{S} * \mathrm{C} * \mathrm{M}$ & 8.7 & 16 & 0.93 & 7.1 & 16 & 0.97 & 20.0 & 16 & 0.22 & 25.4 & 16 & 0.06 \\
\hline
\end{tabular}

The upper part of the table shows the results for the models that included data from conspecific and control soils for all 7 species, while the lower part shows the results for models that included data from conspecific, grass-conditioned and control soils for 5 plant species (See Methods section). Significant results $(p<0.05)$ are shown in bold, and marginally significant results $(0.05 \leq p<0.1)$ are shown in italics

find soil-moisture effects on plant-soil feedbacks in terms of plant biomass. Further, in line with another previous study (Fry et al. 2018), we showed that the direct effects of soil moisture on plant biomass, as well as on plant biomass allocation, were considerably stronger than soil moisture-modulated plant-soil feedback effects. While plants can benefit from soil microbes when exposed to drought stress (de Vries et al. 2020; Kannenberg and Phillips 2017; Valliere and Allen 2016), the Geranium species in our experiment did not benefit more from the microbial community conditioned by conspecifics than from the microbial community in unconditioned or grass-conditioned control soils. Possibly, beneficial effects of soil communities on plant performance under drought stress may be more evident in in nutrient-poor systems (Valliere and Allen 2016), and may therefore possibly have been limited in the soil collected for our experiment.

In our study, soil-moisture effects on plant-soil feedbacks could only be detected when plant-soil feedback effects on relative root weight were calculated as response ratios between conspecific and unconditioned
$\left(\mathrm{PSF}_{\text {unplanted }}\right)$ or grass-conditioned soils ( $\left.\mathrm{PSF}_{\text {grass }}\right) . \mathrm{Ge}$ ranium species experienced the most negative $\mathrm{PSF}_{\text {unplanted }}$ effects on relative root weight under the driest conditions ( $5 \%$ soil moisture). This suggests that under these conditions the plants were most susceptible to, or more strongly impacted by, antagonistic soil biota accumulated by conspecifics, such as root herbivores or pathogens (Atkinson and Urwin 2012; Franco et al. 2019), resulting in a slight decrease of their relative root weight (Franco et al. 2020). While correlations between Geranium biomass in the first phase and the second phase indicated that abiotic feedback effects were likely limited in this study, it is impossible to fully rule out that differences in nutrient content between unplanted control and conspecific soils may have had the most negative impacts on relative root weight under the lowest soil-moisture content. We speculate that the negative plant-soil feedback effects on relative root weight under dry conditions may have consequences for plant performance in the longer term. The plants appear to have a maladaptive relative root weight response to drought, and this effect was further strengthened by the own soil 

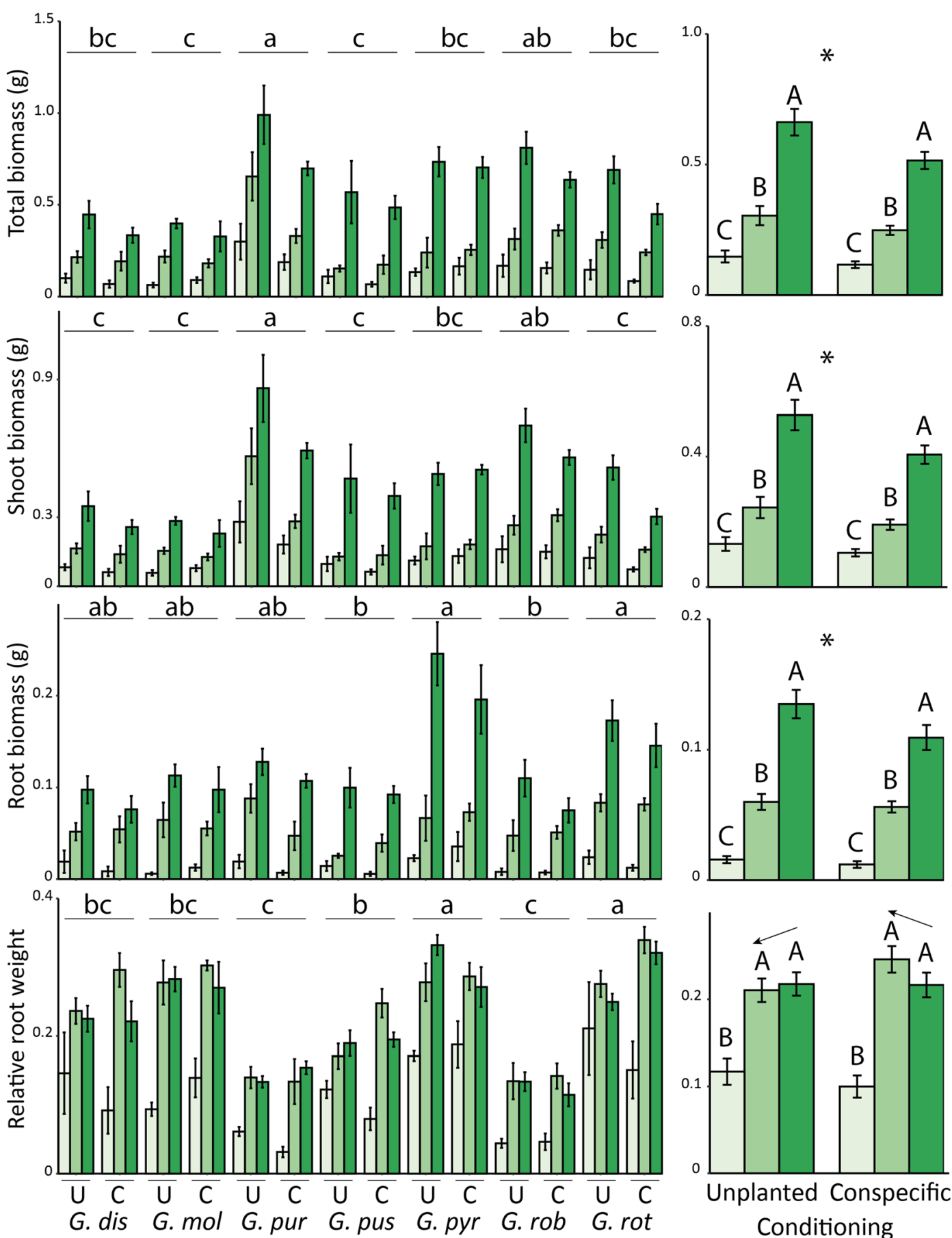

Plant species

Fig. 3 Plant biomass responses of seven different Geranium species (Table 1) to soil conditioning (unplanted control vs. conspecific) and three soil-moisture levels $(5,10,20 \% \mathrm{w} / \mathrm{w})$. The left four panels show average total, shoot and root biomass and relative root weight (root biomass/total biomass) of all seven species in response to unplanted control (U) and conspecific soil (C). The right four panels show the same soil-conditioning and soilmoisture effects, but averaged over plant species. Soil-moisture
$5 \%$

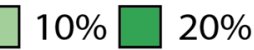

levels are colour-coded. Small letters indicate significant differences between species based on post-hoc analysis. Capital letters indicate significant differences in biomass response between soil moisture levels, asterisks (*) indicate significant differences between soil conditioning treatments, and arrows visualize a significant conditioning*moisture interaction. Bars represent averages \pm standard errors 


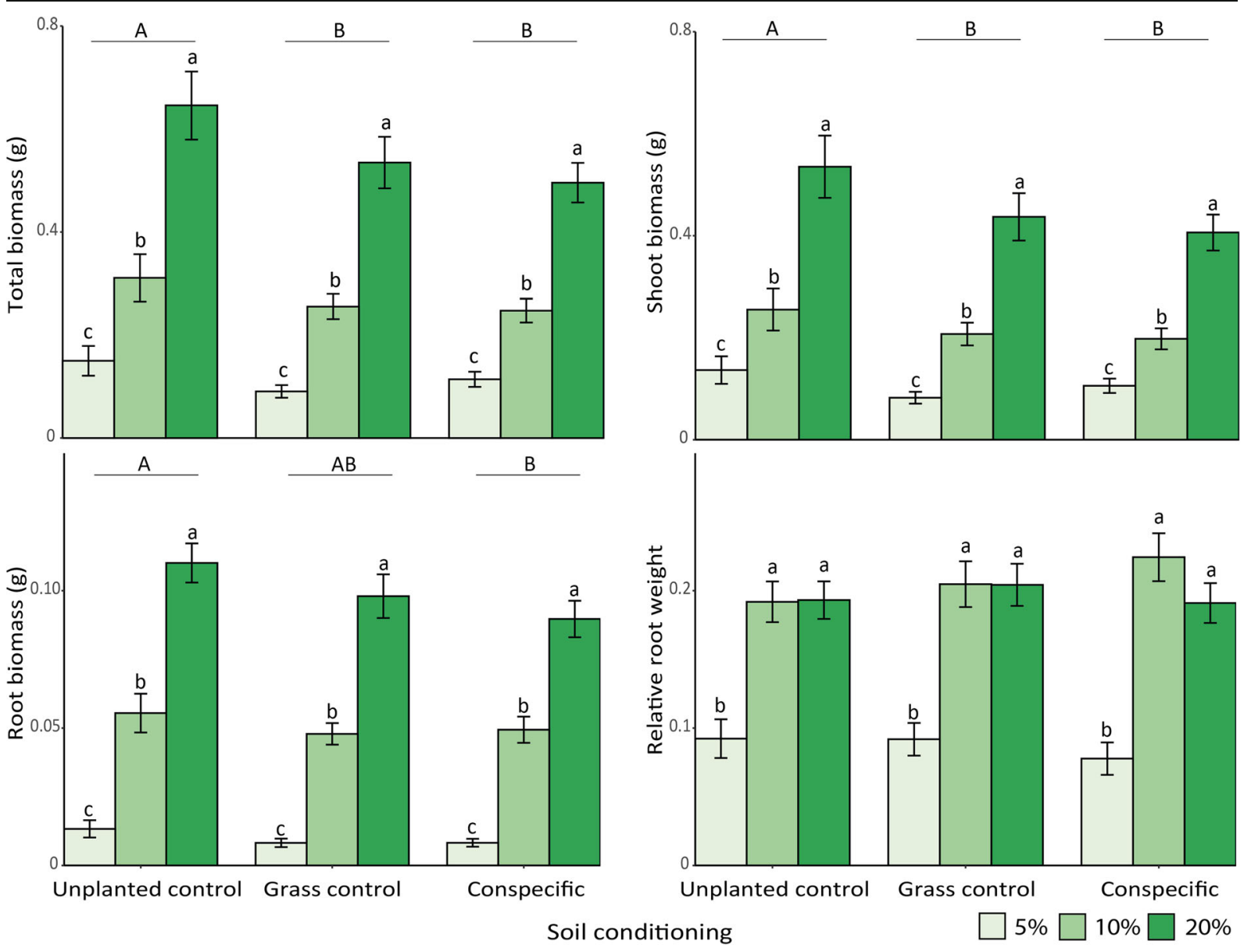

Fig. 4 Plant biomass responses to unplanted control, grass control and conspecific soil under three soil-moisture treatments $(5,10$ and $20 \% \mathrm{w} / \mathrm{w}$ ), averaged over five Geranium species (see Methods section). Separate panels show total biomass (g), shoot biomass $(\mathrm{g})$, root biomass $(\mathrm{g})$ and relative root weight (root

community. In contrast to $\mathrm{PSF}_{\text {unplanted }}$ values, $\mathrm{PSF}_{\text {grass }}$ values were species-specific and either positive or negative, but only under the driest conditions. This suggests that grass-conditioned soil communities functionally differed from unconditioned soil communities, and that under the driest conditions Geranium plants responded in species-specific ways to grass conditioning.

In contrast to a previous study with the same plant species (Wilschut et al. 2019), and regardless of soil moisture, plant-soil feedbacks on biomass did not differ among the Geranium species. Overall Geranium biomass production in soil conditioned by conspecifics was lower than in unplanted control soil, but typically similar to that of conspecific plants grown in grassconditioned control soil. Soil conditioning by plants therefore had a general effect on plant biomass, possibly biomass/total biomass). Soil-moisture levels are colour-coded. Capital letters represent significant differences between soilconditioning-treatment levels based on post-hoc analysis, and small letters indicate significant differences between moisture treatments. Bars represent averages \pm standard errors

via a decrease in nutrients, and species-specific accumulation of soil antagonists during the soil-conditioning phase appeared to be limited. While the length of our conditioning phase should have been long enough to yield significant plant-soil feedback effects (Lepinay et al. 2018; Speek et al. 2015), a shorter soil conditioning phase than in the previous study ( 8 instead of 12 weeks), or the use of a soil inoculum that possibly contained fewer pathogens or root herbivores may explain the lack of clear species-specific feedback effects on biomass responses other than relative root weight.

Drought has well-known effects on biomass allocation, as both annual and perennial plants typically increase their relative root weight in order to maximize water uptake (Eziz et al. 2017; Poorter et al. 2012). However, in our study relative root weight was lowest 
under the driest conditions, indicating that the examined species invested less in root biomass, rather than more, in response to severe drought. Possibly, the examined Geranium species lack the capability to show this plastic response to severe drought, but this remains unknown. Alternatively, the use of relatively shallow pots of limited size $(0.5 \mathrm{~L})$ did not allow plants to show a root foraging response to drought (Turner 2019). Based on the variation in Ellenberg ecological indicator values for soil moisture (Hill et al. 1999), we expected that direct drought effects on plant performance would also be species-specific. However, biomass responses to soil moisture were surprisingly homogeneous across species, as all species showed a weaker performance in response to decreasing soil moisture. We therefore did not test for potential relationships between Ellenberg values and plant-soil feedback effects. A likely explanation for the lack of species-specific responses is that Ellenberg soil-moisture values may best reflect soil moisture in the driest time of the year (Schaffers and Sýkora 2000), and therefore may not correctly represent soil moisture in the actual growing period of the examined species. Instead of Ellenberg values, plant traits, such as water use efficiency, could be used to select species for future plant-soil feedback studies in which the interactive effects of plant identity and soil moisture on plant performance are examined. As plant communities in temperate regions contain an increasing proportion of thermophilic plant species (e.g. Tamis et al. 2005), it is important to expand our knowledge on how drought may directly, and through changes in soil communities, affect individual plant performance and plant-plant interactions (Kaisermann et al. 2017), in order to understand future plant community dynamics. Ideally, such plant-soil feedback studies that incorporate abiotic impacts should also be performed in the field, as under field conditions the importance of plant-soil feedbacks on plant performance and community composition may be most reliably determined (De Long et al. 2019b; Heinen et al. 2020; Heinze et al. 2020).

We conclude that decreases in soil moisture modified soil feedback effects on plants, but that these effects were subtle and limited to plant biomass allocation. Direct effects of soil moisture on plant performance were considerably stronger than soil feedbackmediated effects. Therefore, the indirect effects of drought, via altered impacts of their associated soil biota, may be of limited importance for the natural performance of the plant species in this study. However, in our study, we only examined the effects of drought on feedback responses, whereas drought-mediated shifts in soil communities during the conditioning phase may have stronger effects on plant-soil feedbacks (Kaisermann et al. 2017; Lau and Lennon 2012). To better understand plant-community responses to drought events, future studies should use plant species from various ecological spectra to assess the relative importance of direct and plant-soil feedback-mediated effects of drought on plant performance.

Supplementary Information The online version contains supplementary material available at https://doi.org/10.1007/s11104021-04861-9.

Acknowledgements We thank Beate Rüter, Maximilian Fuchs, Otmar Ficht, Madhav Thakur and Cedric Gutfreund for technical assistance, and Tis Voortman for her contribution to Fig. 1.

Funding Open Access funding enabled and organized by Projekt DEAL.

Open Access This article is licensed under a Creative Commons Attribution 4.0 International License, which permits use, sharing, adaptation, distribution and reproduction in any medium or format, as long as you give appropriate credit to the original author(s) and the source, provide a link to the Creative Commons licence, and indicate if changes were made. The images or other third party material in this article are included in the article's Creative Commons licence, unless indicated otherwise in a credit line to the material. If material is not included in the article's Creative Commons licence and your intended use is not permitted by statutory regulation or exceeds the permitted use, you will need to obtain permission directly from the copyright holder. To view a copy of this licence, visit http://creativecommons.org/licenses/by/4.0/.

\section{References}

Atkinson NJ, Urwin PE (2012) The interaction of plant biotic and abiotic stresses: from genes to the field. J Exp Bot 63:35233543. https://doi.org/10.1093/jxb/ers100

Augé RM (2001) Water relations, drought and vesiculararbuscular mycorrhizal symbiosis. Mycorrhiza 11:3-42. https://doi.org/10.1007/s005720100097

Bardgett RD, van der Putten WH (2014) Belowground biodiversity and ecosystem functioning. Nature 515:505. https://doi. org/10.1038/nature13855

Bates D, Maechler M, Bolker B, Walker S, Christensen RHB, Singmann H, Dai B, Grothendieck G, Green P, Bolker MB (2015) Package 'Ime4'. Convergence 12:2

Berendsen RL, Pieterse CMJ, Bakker PAHM (2012) The rhizosphere microbiome and plant health. Trends Plant Sci 17: 478-486. https://doi.org/10.1016/j.tplants.2012.04.001 
Bezemer TM, Fountain MT, Barea JM, Christensen S, Dekker SC, Duyts H, van Hal R, Harvey JA, Hedlund K, Maraun M, Mikola J, Mladenov AG, Robin C, de Ruiter PC, Scheu S, Setälä H, Šmilauer P, van der Putten WH (2010) Divergent composition but similar function of soil food webs of individual plants: plant species and community effects. Ecology 91:3027-3036. https://doi.org/10.1890/09-2198.1

Ciais P, Reichstein M, Viovy N, Granier A, Ogée J, Allard V, Aubinet M, Buchmann N, Bernhofer C, Carrara A (2005) Europe-wide reduction in primary productivity caused by the heat and drought in 2003. Nature 437:529-533

Cortois R, Schröder-Georgi T, Weigelt A, Putten WH, De Deyn GB (2016) Plant-soil feedbacks: role of plant functional group and plant traits. J Ecol 104:1608-1617. https://doi. org/10.1111/1365-2745.12643

De Deyn GB, Raaijmakers CE, Zoomer HR, Berg MP, de Ruiter PC, Verhoef HA, Bezemer TM, van der Putten WH (2003) Soil invertebrate fauna enhances grassland succession and diversity. Nature 422:711-713. https://doi.org/10.1038 /nature 01548

De Long JR, Fry EL, Veen GF, Kardol P (2019a) Why are plantsoil feedbacks so unpredictable, and what to do about it? Funct Ecol 33:118-128. https://doi.org/10.1111/13652435.13232

De Long JR, Heinen R, Steinauer K, Hannula SE, Huberty M, Jongen R, Vandenbrande S, Wang M, Zhu F, Bezemer TM (2019b) Taking plant-soil feedbacks to the field in a temperate grassland. Basic Appl Ecol 40:30-42. https://doi. org/10.1016/j.baae.2019.08.001

de Vries FT, Liiri ME, Bjørnlund L, Setälä HM, Christensen S, Bardgett RD (2012) Legacy effects of drought on plant growth and the soil food web. Oecologia 170:821-833

de Vries FT, Griffiths RI, Bailey M, Craig H, Girlanda M, Gweon HS, Hallin S, Kaisermann A, Keith AM, Kretzschmar M, Lemanceau P, Lumini E, Mason KE, Oliver A, Ostle N, Prosser JI, Thion C, Thomson B, Bardgett RD (2018) Soil bacterial networks are less stable under drought than fungal networks. Nat Commun 9:3033. https://doi.org/10.1038 /s41467-018-05516-7

de Vries FT, Griffiths RI, Knight CG, Nicolitch O, Williams A (2020) Harnessing rhizosphere microbiomes for droughtresilient crop production. Science 368:270-274. https://doi. org/10.1126/science.aaz5192

Eziz A, Yan Z, Tian D, Han W, Tang Z, Fang J (2017) Drought effect on plant biomass allocation: A meta-analysis. Ecol Evol 7:11002-11010. https://doi.org/10.1002/ece3.3630

Fox J, Weisberg S, Adler D, Bates D, Baud-Bovy G, Ellison S, Firth D, Friendly M, Gorjanc G, Graves S (2012) Package 'car'. R Foundation for Statistical Computing, Vienna

Franco ALC, Gherardi LA, de Tomasel CM, Andriuzzi WS, Ankrom KE, Shaw EA, Bach EM, Sala OE, Wall DH (2019) Drought suppresses soil predators and promotes root herbivores in mesic, but not in xeric grasslands. Proc Natl Acad Sci 116:12883-12888. https://doi.org/10.1073 /pnas.1900572116

Franco ALC, Gherardi LA, Tomasel CM, Andriuzzi WS, Ankrom KE, Bach EM, Guan P, Sala OE, Wall DH, Holeski L (2020) Root herbivory controls the effects of water availability on the partitioning between above- and below-ground grass biomass. Funct Ecol 34:2403-2410. https://doi.org/10.1111 /1365-2435.13661
Fry EL, Johnson GN, Hall AL, Pritchard WJ, Bullock JM, Bardgett RD (2018) Drought neutralises plant-soil feedback of two mesic grassland forbs. Oecologia 186:1113-1125. https://doi.org/10.1007/s00442-018-4082-x

Heinen R, Hannula SE, De Long JR, Huberty M, Jongen R, Kielak A, Steinauer K, Zhu F, Bezemer TM (2020) Plant community composition steers grassland vegetation via soil legacy effects. Ecol Lett 23:973-982. https://doi.org/10.1111 /ele.13497

Heinze J, Wacker A, Kulmatiski A (2020) Plant-soil feedback effects altered by aboveground herbivory explain plant species abundance in the landscape. Ecology 101:e03023. https://doi.org/10.1002/ecy.3023

Hill MO, Mountford J, Roy D, Bunce RGH (1999) Ellenberg's indicator values for British plants. ECOFACT, vol 2 technical annex. Institute of Terrestrial Ecology, Wallingford

Kaisermann A, Vries FT, Griffiths RI, Bardgett RD (2017) Legacy effects of drought on plant-soil feedbacks and plant-plant interactions. New Phytol 215:1413-1424. https://doi. org/10.1111/nph.14661

Kannenberg SA, Phillips RP (2017) Soil microbial communities buffer physiological responses to drought stress in three hardwood species. Oecologia 183:631-641. https://doi. org/10.1007/s00442-016-3783-2

Kardol P, Bezemer TM, van der Putten WH (2006) Temporal variation in plant-soil feedback controls succession. Ecol Lett 9:1080-1088. https://doi.org/10.1111/j.14610248.2006.00953.x

Kardol P, Campany CE, Souza L, Norby RJ, Weltzin JF, Classen AT (2010) Climate change effects on plant biomass alter dominance patterns and community evenness in an experimental old-field ecosystem. Glob Change Biol 16:26762687. https://doi.org/10.1111/j.1365-2486.2010.02162.x

Klironomos JN (2002) Feedback with soil biota contributes to plant rarity and invasiveness in communities. Nature 417: 67-70. https://doi.org/10.1038/417067a

Lau JA, Lennon JT (2012) Rapid responses of soil microorganisms improve plant fitness in novel environments. Proc Natl Acad Sci USA 109:14058-14062. https://doi.org/10.1073 /pnas. 1202319109

Lenth R, Singmann H, Love J, Buerkner P, Herve M (2018) Emmeans: estimated marginal means, aka least-squares means. R package version 1.1. https://CRAN.Rproject. org/package=emmeans

Lepinay C, Vondráková Z, Dostálek T, Münzbergová Z (2018) Duration of the conditioning phase affects the results of plantsoil feedback experiments via soil chemical properties. Oecologia 186:459-470. https://doi.org/10.1007/s00442017-4033-y

Li J, Meng B, Chai H, Yang X, Song W, Li S, Lu A, Zhang T, Sun W (2019) Arbuscular Mycorrhizal Fungi Alleviate Drought Stress in C3 (Leymus chinensis) and C4 (Hemarthria altissima) Grasses via Altering Antioxidant Enzyme Activities and Photosynthesis. Front Plant Sci 10. https://doi.org/10.3389/fpls.2019.00499

Maestre FT, Delgado-Baquerizo M, Jeffries TC, Eldridge DJ, Ochoa V, Gozalo B, Quero JL, García-Gómez M, Gallardo A, Ulrich W, Bowker MA, Arredondo T, Barraza-Zepeda C, Bran D, Florentino A, Gaitán J, Gutiérrez JR, HuberSannwald E, Jankju M, Mau RL, Miriti M, Naseri K, Ospina A, Stavi I, Wang D, Woods NN, Yuan X, Zaady E, 
Singh BK (2015) Increasing aridity reduces soil microbial diversity and abundance in global drylands. Proc Natl Acad Sci 112:15684-15689. https://doi.org/10.1073 /pnas. 1516684112

Meijer SS, Holmgren M, Van der Putten WH (2011) Effects of plant-soil feedback on tree seedling growth under arid conditions. J Plant Ecol 4:193-200. https://doi.org/10.1093 /jpe/rtr011

Meisner A, de Boer W (2018) Strategies to maintain natural biocontrol of soil-borne crop diseases during severe drought and rainfall events. Front Microbiol 9. https://doi. org/10.3389/fmicb.2018.02279

Poorter H, Niklas KJ, Reich PB, Oleksyn J, Poot P, Mommer L (2012) Biomass allocation to leaves, stems and roots: metaanalyses of interspecific variation and environmental control. New Phytol 193:30-50. https://doi.org/10.1111/j.14698137.2011.03952.x

Pugnaire FI, Morillo JA, Peñuelas J, Reich PB, Bardgett RD, Gaxiola A, Wardle DA, van der Putten WH (2019) Climate change effects on plant-soil feedbacks and consequences for biodiversity and functioning of terrestrial ecosystems. Sci Adv 5:eaaz1834. https://doi.org/10.1126/sciadv.aaz1834

R Core Development Team (2012) R: A language and environment for statistical computing. R Foundation for Statistical Computing, Vienna, 2012. ISBN 3-900051-07-0

Schaffers AP, Sýkora KV (2000) Reliability of Ellenberg indicator values for moisture, nitrogen and soil reaction: a comparison with field measurements. J Veg Sci 11:225-244. https://doi. org $/ 10.2307 / 3236802$

Sheik CS, Beasley WH, Elshahed MS, Zhou X, Luo Y, Krumholz LR (2011) Effect of warming and drought on grassland microbial communities. ISME J 5:1692-1700

Shukla P, Skeg J, Buendia EC, Masson-Delmotte V, Pörtner H-O, Roberts D, Zhai P, Slade R, Connors S, van Diemen S (2019) Climate Change and Land: an IPCC special report on climate change, desertification, land degradation, sustainable land management, food security, and greenhouse gas fluxes in terrestrial ecosystems. IPCC, Geneva

Speek TAA, Schaminée JHJ, Stam JM, Lotz LAP, Ozinga WA, van der Putten WH (2015) Local dominance of exotic plants declines with residence time: a role for plant-soil feedback? AoB Plants 7. https://doi.org/10.1093/aobpla/plv021
Tamis WM, Zelfde MT, Meijden R, Haes HU (2005) Changes in vascular plant biodiversity in the Netherlands in the 20th century explained by their climatic and other environmental characteristics. Clim Change 72:37-56. https://doi. org/10.1007/s10584-005-5287-7

Turner NC (2019) Imposing and maintaining soil water deficits in drought studies in pots. Plant Soil 439:45-55. https://doi. org/10.1007/s11104-018-3893-1

Valliere JM, Allen EB (2016) Interactive effects of nitrogen deposition and drought-stress on plant-soil feedbacks of Artemisia californica seedlings. Plant Soil 403:277-290. https://doi.org/10.1007/s11104-015-2776-y

van Dam NM, Bouwmeester HJ (2016) Metabolomics in the rhizosphere: tapping into belowground chemical communication. Trends Plant Sci 21:256-265. https://doi.org/10.1016 j.tplants.2016.01.008

van der Putten WH, Van Dijk C, Peters BAM (1993) Plantspecific soil-borne diseases contribute to succession in foredune vegetation. Nature 362:53-56

van der Putten WH, Bardgett RD, Bever JD, Bezemer TM, Casper BB, Fukami T, Kardol P, Klironomos JN, Kulmatiski A, Schweitzer JA, Suding KN, Van de Voorde TFJ, Wardle DA (2013) Plant-soil feedbacks: the past, the present and future challenges. J Ecol 101:265-276. https://doi. org/10.1111/1365-2745.12054

Williams A, de Vries FT (2020) Plant root exudation under drought: implications for ecosystem functioning. New Phytol 225:1899-1905. https://doi.org/10.1111/nph.16223

Wilschut RA, van der Putten WH, Garbeva P, Harkes P, Konings W, Kulkarni P, Martens H, Geisen S (2019) Root traits and belowground herbivores relate to plant-soil feedback variation among congeners. Nat Commun 10:1564. https://doi. org/10.1038/s41467-019-09615-x

Wu Z, Dijkstra P, Koch GW, PeÑUelas J, Hungate BA (2011) Responses of terrestrial ecosystems to temperature and precipitation change: a meta-analysis of experimental manipulation. Glob Change Biol 17:927-942. https://doi.org/10.1111 /j.1365-2486.2010.02302.x

Publisher's note Springer Nature remains neutral with regard to jurisdictional claims in published maps and institutional affiliations. 